\title{
Al-Khalīlayn Dalam Romantisme Sastra Arab
}

\author{
Yusuf Haikal \\ Universitas Islam Negeri Sunan Kalijaga Yogyakarta \\ yusufhaikal57@gmail.com
}

\section{Article History:}

Received: January 30, 2021

Revised: February 28, 2021

Accepted: March 15, 2021

Published: March 18, 2021

https://doi.org/10.36835/ al-irfan.v4i1.4305

\section{Keywords:}

Romantisme, Sastra Arab,

Khalīl Muthran, Khalīl

Gibran

\begin{abstract}
This article aims to provide an overview of romanticism in Arabic literature, in particular through two important figures in this school. important in the foundation and development of romanticism in Arabic literature. The method used in this article is descriptive qualitative and literature study. This study also uses the technique of observing and taking notes in data collection. From the discussion it can be concluded that the flow of romanticism is one of the popular streams that first appeared in the 18th century in Europe and entered the Arab region at the beginning of the 20th century. The entry of romanticism into the Arab world was pioneered by Khalil Muthran. Apart from Khalīl Muthran, there is another Arabic literary figure who popularized this romanticism, namely Khalil Gibran. These two Khalils were important figures in the emergence and development of romanticism in Arabic literature. This can be seen from the life history of both of them who both studied literature in western countries. In addition, the works produced by these two figures show a strong romantic style, which strengthens the character of the two in Arabic literary romanticism
\end{abstract}




\section{Pendahuluan}

Sastra dalam kebudayaan Arab adalah suatu hal yang tidak dapat dipisahkan. Sejak jaman jahiliyyah, masa munculnya Islam, masa Umawiyyah, masa Abbasiyyah, masa Daulah Utsmaniyyah, hingga masa modern seperti sekarang ini, sastra Arab terus eksis dan berkembang. Perkembangan sastra Arab di masa sekarang ini tak luput dari perkembangan keilmuan dan kebudayaan barat. Sehingga, saat ini muncul banyak aliran-aliran sastra di kesusastraan Arab yang mengikuti aliran-aliran kesusastraan barat. Klasisme, Romantisme, Parnasianisme, Realisme, Simbolisme, Surealisme, dan Eksistensialisme merupakan contoh aliran-aliran kesusastraan barat yang diadaptasi oleh sastrawan kontemporer Arab. Meskipun aliran-aliran ini merupakan adaptasi di dalam kesusastraan Arab, namun sejatinya bentuk dan inti dari aliran-aliran ini sudah digunakan oleh para sastrawan Arab, bahkan sejak zaman jahiliyyah. Salah satunya adalah aliran romantisme yang menitikberatkan pada luapan emosi dan imajinasi yang kuat dengan menomorduakan akal dan realitas sebagai batasannya.

Umru'ul Qays merupakan salah seorang sastrawan masa jahiliyyah yang terkenal dengan puisi-puisinya yang bercorak romantisme, sekalipun awal mula aliran romantisme baru muncul pada abad ke-18 di Eropa. Umru'ul Qays pernah dalam syairnya melukiskan gelapnya malam bagai badai laut tengah karena keresahan yang sedang dialaminya. Ia juga pernah menggambarkan dan mensifati pujaan hatinya, Unaizah, bak kaca tanpa retak dan juga keindahan mahligai rambutnya yang terurai seperti mayang kurma. ${ }^{1}$

Aliran romantisme merupakan salah satu aliran yang popular hingga saat ini, aliran ini sendiri pertama kali muncul pada abad ke-18 di Eropa dan masuk ke wilayah arab pada awal abad ke-20. Masuknya aliran romantisme ke dunia Arab dipelopori oleh Khalīl Muthran (1873-1949) sebagai reaksi atas aliran sastra

${ }^{1}$ Kamil Sukron, Teori Kritik Sastra Arab Klasik dan Modern. Jakarta: Raja Grafindo Persada, 2012. hal 165. 
neo-klasik yang dipopulerkan oleh Al-Barudi. ${ }^{2}$ Aliran neo-klasik yang bercirikan rasional dan realisme dihadapkan dengan nuansa dan aliran baru, yaitu romantisme, yang cenderung lebih menitikberatkan pada emosi dan imajinasi dan menomorduakan rasionalitas dan realitas.

Selain Khalīl Muthran, terdapat satu lagi tokoh sastrawan Arab yang mempopulerkan aliran romantisme ini, yaitu Khalīl Gibran. Dua Khalīl ini adalah tokoh penting dalam pondasi dan perkembangan romantisme dalam sastra Arab. Namun, dalam beberapa referensi, penulis temukan kesalahan dalam penyebutan sosok pelopor romantisme dalam sastra Arab, disebutkan bahwa yang menjadi pelopor adalah Khalīl Gibran, bukan Khalīl Muthran. Hal ini disebabkan oleh ketenaran Khalìl Gibran yang melebihi ketenaran Khalīl Muhtran. Maka dalam tulisan ini, penulis berusaha menjelaskan kedua tokoh popular dalam aliran romantisme sastra Arab ini serta menganalisis karya kedua Khalīl ini berdasarkan teori romantisme yang ada sehingga kita bisa ketahui corak romantisme dalam sastra Arab berdasarkan dua tokoh penting ini.

\section{Isi}

\section{Metode Penelitian}

Metode penelitian adalah sebuah langkah kerja berupa kegiatan meneliti, menganalisis, dan mengkaji objek sasaran penelitian untuk menarik sebuah kesimpulan berdasar pada proses kerja sebelumnya. ${ }^{3}$ Pada artikel ini, peneliti menggunakan metodelogi penelitian kualitatif deskriptif. Bodgan dan Taylor sebagaimana dikutip oleh Moleong dalam bukunya menjelaskan bahwa penelitian kualitatif deskriptif adalah sebuah prosedur penelitian yang

\footnotetext{
2 Said Husain Manshur, al-Tajdīd fĩ syi'ri khalīl Muthran. Iskandariah: al-Hay'ah alMishriyyah al-'Ammah lil-Kitāb, 1977. hal 180

${ }^{3}$ Abdul Mukit, Filsafat Manusia dan Implikasinya Terhadap Rumusan Pendidikan Islam. Jurnal Al-Irfan, 3(2), 2020. Hal 182.
} 
menghasilkan data deskriptif berupa kata-kata tertulis atau lisan dari suatu hal yang diamati. 4

Penelitian ini juga menggunakan studi pustaka yang merupakan sebuah metode pengumpulan data yang diarahkan kepada pencarian data dan informasi melalui dokumen-dokumen, baik dokumen tertulis, foto-foto, gambar, maupun dokumen elektronik yang dapat mendukung dalam proses penulisan. ${ }^{5}$

Teknik penelitian yang peneliti gunakan adalah teknik simak dan catat, yakni peneliti menyimak dan membaca langsung dari sumber-sumber terkait yang kredibel kemudian data yang didapat diolah, disusun dan juga dianalisis. Pertama-tama peneliti menyusun dan mengolah data terkait biografi kedua tokoh, kemudian peneliti juga menganalisis satu puisi dari masing-masing tokoh dengan teori romantisme sastra yang sudah disajikan terlebih dahulu sebagai landasan analisis dan teori.

\section{Biografi Khalīl Muthran.}

Khalīl Mutran adalah seorang sastrawan terkenal dan terhebat di masa modern, bahkan Khalīl Muthran disandingkan sejajar dengan Ahmad Syauqi, Sang 'Amìrusy-Syu'ara', dan Ibrahim Hafidz. Muthran dilahirkan di Ba'labak, Lebanon, pada tahun 1872. Ia merupakan seorang anak dari ayah yang beragama Kristen Katolik dan ibu yang berkebangsaan Palestina. Kedua orang tua Muthran memiliki pengaruh yang besar dalam pembentukan dirinya sebagai sastrawan ulung, telebih ibu Muthran yang juga seorang penyair. ${ }^{6}$

Dia menerima prinsip-prinsip menulis dan dasar-dasar aritmatika di sebuah sekolah dasar di Zahle, kemudian melanjutkan pendidikannya di sekolah Patriarki Katolik Roma di Beirut. Muthran tinggal di sana hingga usia tujuh belas

${ }^{4}$ Lexy J Moloeng, Metodologi Penelitian Kualitatif. Bandung: Remaja Rosdakarya, 2017. hal 4

${ }^{5}$ Sugiyono, Metode Penelitian Kuantitatif Kualitatif Dan RED. Bandung: Alfabeta, 2005. hal 83

${ }^{6}$ Anal-Bahr.com, Bachts an Sya'iri Khalīl Muthran Sya'iri al-Qathrain, diakses dari https:/ / analbahr.com/بحث-عن-الثاعر-خليل-مطر ان-شاعر -القطرين pada 8 November 2020 pukul 13.05 
tahun, di sekolah tersebut, Muthran mempelajari bahasa Arab di tangan seorang penulis pada masanya Ibrahim Al-Yazji, sehingga memperoleh budaya Arab yang sangat baik. Di sekolah ini pula, ia mampu menulis dengan bahasa Prancis dan memperoleh seni dan gayanya, jadi ia menggabungkan dua budaya (Arab dan Prancis), sesuatu yang mengembangkan bakatnya dan menarik perhatiannya, terutama ketika ia mulai mengarang puisi melawan Ottoman yang memerintah negaranya, yang membuatnya mendapatkan ketenaran sebagai seorang sosok revolusioner yang berjuang dalam melawan ketidakadilan dan tirani $^{7}$

Setelah Khalīl Mutran lulus dari sekolah patriarki, ia mulai menulis puisi melawan kesewenang-wenangan Ottoman. Tulisan yang ia gubah seringkali membahayakan nyawanya. Hal inilah yang membuat keluarga Muthran mengirimnya ke Paris. Di sana, ia melihat karya-karya pelopor sastra Prancis seperti Cade Musier, Muthran juga sangat menyukai dan mempelajari sastra dan teater Shakespeare, seorang tokoh romantisme terkenal dari Prancis. ${ }^{8}$ Di Paris Muthran juga belajar bahasa Spanyol, ia pun berpikiran untuk pergi ke Chile, tetapi takdir mendorongnya ke Mesir, yang merupakan "kandang" terakhir Khalīl Mutran, sebuah tempat yang menjadi permulaan langkah Muthran, karena Mesir pada waktu itu adalah tempat pertemuan bagi para pencari kebebasan. ${ }^{9}$

Kedatangan Khalīl Mutran ke Mesir bertepatan dengan kematian salah satu profesor Sekolah Patriarkal yang sangat disayangi oleh penyair itu, dan dia sendiri adalah pendiri surat kabar Mesir Al-Ahram. Karena itu, saudara laki-laki almarhum menawarkan Khalīl Mutran untuk menjadi editor di koran Al-Ahram, dan hanya dalam waktu singkat Khalīl Mutran menjadi seorang jurnalisme yang menonjol, karena pengalamannya dalam menyunting dan menulis, kefasihan

7 ibid

${ }^{8}$ Nojomy.com, Khalīl Muthran Qishshatu chayati syō'ir al-Qathrain, diakses di https:// nojomy.com/writers/خليل-مطر ان-قصة-حياة pada 8 November 2020 pukul 13.50.

${ }^{9}$ Anal-Bahr.com, Op. Cit. 
dalam gaya dan ekspresi, dan ketulusannya dalam menyajikan dan menganalisis peristiwa.

Namun Muthran meninggalkan Al-Ahram setelah melakukan percobaan yang berlangsung selama delapan tahun, dan memutuskan untuk mendirikan korannya sendiri, di mana ia menerbitkan majalah Mesir pada tahun 1900, yang merupakan majalah dua bulanan, kemudian ia menerbitkan majalah Al-Jawaib (harian) ${ }^{10}$. Karena pengetahuannya yang luas tentang urusan teater, dia dipercaya untuk mengelola rombongan nasional sejak 1938, dan untuk ini dia melakukan layanan yang luar biasa, termasuk karyanya dalam menerjemahkan banyak karya manusia abadi, seperti drama Shakespeare (Othello - Hamlet Maqbet - The Merchant of Venice) ${ }^{11}$

Pada tahun 1949, pada umur 77 tahun Khalīl Muthran wafat, ia dikenal sebagai penyair dengan penuh nilai kemanusiaan, penyair yang cerdas dan berintegritas serta selalu menyisipkan pesan menohok di setiap gubahan syair yang dibuatnya. ${ }^{12}$ Muthran adala seorang pembaharu dalam aliran kesusastraan Arab, ia membawa aliran romantisme barat ke dalam kesusastraan Arab dan menjadikan aliarn ini berkembang dalam sastra Arab itu sendiri. Muthran dikenal sebagai bapak romantisme sastra Arab, dan langkah serta capaian yang ia raih akan sangat bermanfaat untuk kemajuan aliran sastra Arab di masa mendatang. ${ }^{13}$

\section{Biografi Khalīl Gibran}

Gibran Khalīl Gibran lahir di Lebanon di desa Bcharre pada bulan Januari tahun 1883. ${ }^{14}$ Ayahnya, Khalī Saad Gibran, adalah seorang yang tangguh, kasar, dan dia tidak disukai oleh banyak orang, sedangkan ibunya bernama Kamilah

\footnotetext{
${ }^{10}$ Michel Juha, Khalìl Muthran Bakōrah lì al-Tajdìdi fì al-Syi'ri al-'Arabìy al-Chadìtsìy. Beirut: Dōrul Masīrah, 1981. hal 80

11 Anal-Bahr.com, Op.Cit.

${ }^{12}$ Michel Juha, Op.Cit. hal 81

${ }^{13}$ Ibid hal 7

${ }^{14}$ Jean Gibran dan Khalīl Gibran, Khalìl Gibran chayātuhu wa 'alōmuhu. Kairo: al-Majlis al-A'lō lil-Tsaqūfah, 2015. Hal 29
} 
Rahmah. Gibran tidak bersekolah karena ayahnya tidak menganggap penting masalah ini, jadi dia sering pergi ke pendeta kota, yang segera menyadari keseriusan dan kecerdasannya, dan menghabiskan waktu berjam-jam mengajarinya alfabet, membaca dan menulis, hal inilah yang membuka bidang membaca dan belajar tentang sejarah, sains dan sastra. ${ }^{15}$ Kamileh adalah ibu yang penyayang, ia memiliki ambisi untuk anak-anaknya, dan terlepas dari pendidikan informal, dia memiliki kecerdasan dan kebijaksanaan yang sangat berpengaruh besar pada putranya, Gibran. Fasih berbahasa Arab dan Prancis, artistik dan musik, Kamileh memicu imajinasi Gibran dengan cerita rakyat dan legenda Lebanon serta cerita-cerita lain dari Alkitab. Sifat spiritualnya dan upacara mistik Maronit yang dia hadiri bersama anak-anaknya juga berdampak besar pada kehidupan dan pekerjaan Gibran, di tangan ibunya, Gibran belajar bahasa Arab dan juga melukis. Dalam salah satu karyanya yang paling awal Al-Ajnichah Al-Mutakassirah (Sayap Patah) - Khalīl Gibran dengan jelas mengungkapkan rasa hormat dan kekagumannya yang terdalam terhadap sang ibu, melalui karyanya ia tuliskan: "Kata terindah ysng pernah terucap oleh bibir umat manusia adalah kata" Ibu ", dan panggilan yang paling indah adalah panggilan "wahai ibuku". ${ }^{16}$

Sejak awal, Gibran menunjukkan hasratnya untuk menggambar; dan jika tidak ada kertas di rumah, dia akan pergi keluar dan menghabiskan waktu berjam-jam membuat sketsa di atas salju segar. Pada usia empat tahun, dia sudah menggali beberapa lubang di tanah dan dengan hati-hati kemudian menanam potongan-potongan kertas kecil disitu, sembari berharap panen musim panas akan memberinya persediaan kertas yang banyak. Pada usia enam tahun dia terpesona oleh beberapa cetakan Leonardo Da Vinci tua yang diberikan kepadanya oleh ibunya. Dia tidak pernah melupakan momen yang menentukan

\footnotetext{
جبران خليل جبر ان/ ${ }^{15}$ Mareefa.org, Jibrōn Khalil Jibran, diakses dari https://www.marefa.org pada 8 November 2020 pukul 14.07

16 Gibran National Committee, About Gibran Biography, diakses di http://www.gibranKhalīlgibran.org/AboutGebran/Biography pada 10 november 2020 pukul 10.22
} 
ini, dan penemuan "pria luar biasa" ini berkesan bagi Gibran "seperti jarum kompas untuk kapal yang tersesat di kabut laut" yang membangkitkan dalam dirinya kerinduan untuk menjadi seorang seniman.

Ayah Gibran yang terkenal dengan pribadi yang buruk akhirnya dihukum karena sebuah kasus dan menyebablan semua asetnya disita. Pada tanggal 25 Juni 1895, ibu Khalīl Gibran memutuskan melakukan perjalanan bersama dengan keempat anaknya ke pantai Amerika di New York, meninggalkan ayahnya di Lebanon. Keluarga Gibran menetap di Ujung Selatan Boston, di sana Kamileh mulai bekerja sebagai penjual di jalanan. Gibran adalah satu-satunya anggota keluarganya yang mengejar pendidikan skolastik. Gibran masuk sekolah pada tanggal 30 September 1895, hanya dua bulan setelah kedatangannya ke AS. Karena tidak memiliki pendidikan formal, ia ditempatkan di kelas yang tidak diperingkat yang diperuntukkan bagi anak-anak imigran untuk belajar bahasa Inggris dari awal. Keingintahuan Gibran membawanya ke sisi budaya Boston. Dia tertarik dan terjun pada dunia Teater, Opera, dan Galeri seni. Didasari oleh banyaknya atsar budaya di sekitarnya dan melalui gambar artistiknya, Gibran menarik perhatian guru-gurunya di sekolah umum. Mereka melihat masa depan artistik untuk bocah Lebanon itu dan menuntunnya untuk bertemu dengan Fred Holland Day pada tahun 1896, seorang seniman yang memperkenalkan Gibran pada mitologi Yunani, sastra dunia, tulisan kontemporer, dan fotografi. ${ }^{17}$

Fred Holland Day terus mendorong Gibran untuk memperbaiki gambar dan sketsanya, sehingga membuat gambar Gibran dicetak sebagai desain sampul buku pada tahun 1898. Bersamaan dengan itu, Gibran mulai mengembangkan teknik dan gayanya sendiri yang membawanya memasuki lingkaran Bostonian. Terlepas dari bakat artistiknya yang membuatnya terkenal sejak usia dini, keluarga Gibran memutuskan, dengan persetujuan Gibran, untuk mengirim artis muda itu kembali ke Lebanon untuk menyelesaikan pendidikannya dan belajar

17 Gibran National Committee, Op.Cit. 
bahasa Arab. Pada tahun 1898, Gibran tiba di Beirut untuk mendaftar di CollegeLa Sagesse, sebuah sekolah yang didirikan oleh Maronite yang menawarkan kurikulum nasionalistik yang berpihak pada tulisan, sejarah dan liturgi gereja. Namun, suasana sekolah yang ketat dan disiplin itu tidak disukai Gibran. Dia secara mencolok melanggar kewajiban agama, membolos kelas, dan menggambar sketsa di buku. Di sana, dia bertemu Joseph Howayek, sosok yang menemani Gibran memulai sebuah majalah bernama Al Manara (The Beacon). Mereka berdua berpartisipasi dalam penyuntingannya sementara Gibran juga membuat ilustrasi.

Gibran membenamkan dirinya dalam sastra Arab - kuno dan modern dia belajar bahasa Prancis dan unggul dalam studinya, terutama dalam puisi. Sementara itu, hubungannya dengan ayahnya menjadi tegang karena pengetahuan lanjut Gibran, mendorongnya untuk tinggal bersama sepupunya. Pada tahun 1902 Gibran terpaksa segera kembali ke Boston setelah menerima berita tentang penyakit adiknya Sultana yang mengerikan. Pada tahun 1904, Gibran mulai menulis artikel untuk surat kabar émigré berbahasa Arab Al Muhajer (The Emigrant), menandai karya tulis pertamanya yang diterbitkan. Publikasi pertamanya berjudul Vision, sebuah esai romantis yang menggambarkan seekor burung dalam sangkar di tengah limpahan simbolisme. Tulisan Arabnya memiliki nuansa sehari-hari, yang membuatnya dapat diakses oleh para pendengarnya. Menurut Gibran, aturan bahasa dimaksudkan untuk dilanggar dan dia terus mendorong penulis emigran Arab untuk keluar dari tradisi dan mencari gaya individu. Sepanjang hidupnya, tulisan Arab Gibran tidak menerima pujian kritis yang diterima buku-buku bahasa Inggrisnya, yang membuatnya kemudian lebih berkonsentrasi pada tulisan-tulisan bahasa Inggrisnya.

Karya tulis Arab pertama Gibran keluar pada tahun 1905 dengan penerbitan Nubthah Fi Fan al Musiqa (Musik). Gibran juga memulai kolom di Al Muhajer yang disebut Tears and Laughter yang menjadi dasar bukunya A Tear 
and a Smile. Saat itu, Gibran menerbitkan beberapa puisi Arab dan menulis di surat kabar tentang berbagai topik yang berkaitan dengan cinta, kebenaran, keindahan, kematian, kebaikan dan kejahatan. Pada tahun 1906, Gibran menerbitkan buku Arab keduanya Arayis Al Muruj (The Nymphs of the Valley), kumpulan tiga alegori yang terjadi di Lebanon Utara. Ciri khas publikasi Arab awal Gibran adalah rasa pahit dan kekecewaan yang kuat: tujuan utama Gibran adalah untuk mereformasi masyarakat. Penggunaan ironi, realisme cerita, penggambaran warga kelas dua dan nada anti-ulama kontras dengan tulisan Arab formalistik dan tradisional. Gibran menerbitkan buku Arab ketiganya Al Arwah al Mutamarridah (Spirits Rebellious) pada Maret 1908: kumpulan dari empat teks naratif berdasarkan tulisannya di Al Muhajer (The Immigrant). Pada tanggal 1 Juli 1908, Gibran meninggalkan Boston untuk pergi ke Paris dan belajar di sekolah seni. Setelah kedatangannya, Gibran terpesona oleh kancah budaya Prancis dan memanjakan waktunya memeriksa lukisan di berbagai museum dan pameran seni. Bersama dengan Joseph Howayek, teman sekolahnya di Lebanon, dia membuat sketsa model dan mengunjungi pameran. Kemudian, Gibran pindah ke London bersama rekan penulis Arab Amin Rihani, yang dikagumi Gibran karena kecerdasan dan gaya penulisannya yang sarkastik. Gibran kembali ke AS pada 31 Oktober 1910, mengakhiri semua perjalanannya ke luar negeri untuk menetap dan berkonsentrasi pada tulisannya. ${ }^{18}$

Di New York, Gibran mulai mengerjakan buku berikutnya ;sayap yang patah; - dimulai pada 1906 dan diterbitkan pada Januari 1912. Sayap yang patah -novel Arab terpanjangnya- berkisah tentang Selma Karameh, seorang wanita yang sudah menikah, hubungan cintanya yang naas dengan seorang pria muda membuatnya meninggal saat melahirkan. Pada tahun 1911, Gibran menggambar potret penyair Irlandia WB Yeats, salah satu dari serangkaian potret yang oleh Gibran disebut sebagai seri Kuil Seni. Kemudian, selama Perang Dunia I, Gibran

${ }^{18}$ Gibran National Committee, Op.Cit. 
menjadi pendukung dan penghasut hebat aksi militer Arab bersatu melawan pemerintahan Ottoman. Gibran adalah seorang sosialisator yang hebat dan kepribadian yang menarik yang menarik perhatian tuan rumahnya. Pada tahun 1913, ia bergabung dengan dewan pengurus majalah émigré Arab yang baru didirikan, Al Funun, sebuah majalah berkala yang diterbitkan oleh komunitas berbahasa Arab di New York dan didedikasikan untuk kemajuan masalah sastra dan seni. Refleksi majalah tentang pendekatan liberal Gibran terhadap gaya dan selera membuatnya berkontribusi dengan beberapa artikel yang kemudian menjadi dasar buku bahasa Inggris pertamanya, The Madman. Pada tahun 1913, Gibran mulai mengerjakan The Madman, mengeksplorasi subjek yang membuatnya terpesona sejak saat itu. Dalam upayanya untuk menguasai bahasa Inggris, Gibran beruntung mendapatkan bantuan dan dorongan dari Mary Haskell. Mary, sejak awal, adalah konsultan tulisan-tulisan Gibran dalam bahasa Inggris. Mulai bulan Juni 1914, Gibran mencari komentar Mary tentang sebagian besar keluaran bahasa Inggrisnya saat sedang ditulis dan ditulis ulang: pertama The Madman, lalu The Forerunner, dan terakhir The Prophet, yang penerbitannya pada tahun 1923, buku ini menjadi buku paling fenomenal yang pernah ditulis oleh sang sastrawan ulung. ${ }^{19}$

Pada tahun 1919, kesuksesan Gibran sebagai seniman - sering dibandingkan dengan penyair-pelukis hebat William Blake - mencapai puncaknya dengan publikasi oleh Alfred Knopf dari sebuah volume berjudul Twenty Drawings. Secara bersamaan, Gibran juga menjadi pendiri-presiden sebuah masyarakat sastra bernama Al Rabitat al Qualamiya (The Pen-bond Society). Anggota asli Al Rabitat semuanya adalah penulis Arab-Amerika terkemuka, dan hanya sedikit yang akan menyangkal status Gibran sebagai tokoh Romantik Arab terbesar dan bapak tradisi Romantis abad ke-20. Kesuksesannya sebagai penulis, baik dalam bahasa Arab maupun Inggris,

${ }^{19}$ Gibran National Committee, Op.Cit. 
memberinya landasan untuk mengungkapkan pandangan yang menurutnya perlu didengar oleh sesama orang Arab. Artikel-artikel berbahasa Arabnya di awal 1920-an didominasi oleh pesan bahwa negara-negara Arab yang sedang berkembang harus "hanya mengadopsi aspek-aspek konstruktif dari masyarakat Barat" karena ia khawatir Timur sedang tergoda oleh atraksi-atraksi paling berbahaya di Barat. Pada 1926, Gibran telah menjadi tokoh internasional yang terkenal, tetapi mencari eksposur kosmopolitan yang lebih besar, dia mulai berkontribusi dengan artikel ke jurnal triwulanan The New Orient. Pada tahun yang sama, Gibran mulai menulis Yesus, Anak Manusia, ambisi seumur hidupnya, terutama dengan upaya untuk menggambarkan Yesus seperti yang belum pernah dilakukan orang lain sebelumnya: bagi Gibran, Yesus muncul sebagai manusia, bertindak di alam sekitar. Pada Januari 1927, Mary mengedit buku itu. Pada tahun 1928, kesehatan Gibran mulai memburuk, dan rasa sakit di tubuhnya, akibat keadaan gugupnya, semakin meningkat, mendorong Gibran untuk mencari pertolongan dengan alkohol. Tak lama kemudian, kebiasaan minum Gibran yang berlebihan membuatnya menjadi seorang pecandu alkohol pada puncak masa pelarangan di AS. Pada tahun 1930, kebiasaan minum Gibran yang berlebihan, untuk menghindari rasa sakit di livernya, memperburuk penyakitnya dan harapannya untuk menyelesaikan bagian kedua dari The Prophet (The Garden of the Prophet) menyusut. Pada 10 April 1931, Gibran meninggal pada usia empat puluh delapan tahun di sebuah rumah sakit New York, karena penyebaran kanker di hatinya. ${ }^{20}$

\section{Romantisme}

Romantisme termasuk salah satu aliran sastra paling penting yang pernah berkembang di sejarah dunia barat. ${ }^{21}$ Definisi Romantisme secara rinci dan pasti sendiri menjadi perdebatan panjang antar para sastrawan dan ilmuwan bahasa karena luasnya makna yang terkandung dari kalimat "Romantisme". Hal ini

\footnotetext{
${ }^{20}$ Gibran National Committee, Op.Cit.

21 Nagham 'Ashim Utsman, Ar-R̄̄mansīyah Bachts fī al-Musthalach wa Tārīkhihi wa Madzōhibihi al-Fikriyyah. Al-markaz al-islamiy lil-dirōsat al-istirātījiyyah, 2017. hal 9
} 
sejalan dengan apa yang dikatakan oleh Dr. Muhammad Ghanimi Hilal, bahwasanya, sulit sekali untuk menentukan dan memberikan definisi yang ringkas untuk aliran sastra yang satu ini, yakni romantisme, dan banyak definisi yang beredar dan dibuat oleh beberapa tokoh, namun ditentang dan diingkari oleh tokoh yang lain. ${ }^{22}$ Salah seorang tokoh berkebangsaan jerman Friedrich Schleigl pernah menumpulkan sejumlah definisi-definisi mengenai romantisme dan dari hasil kumpulan tersebut didapati sekitar 125 definisi mengenai romantisme. ${ }^{23}$

Namun, utsman dalam kitabnya ar-Rumansīyyah memberikan kesimpulan mengenai definisi romantisme dengan "sebuah penegasan intelektual dan artistik dari karakter positif untuk antitesis jiwa manusia, bentuk penegasan ini diungkapkan dari dalam hati manusia dengan lebih mengedepankan rasa dan emosi ketimbang akal dan logika". ${ }^{24}$ Kata romantisme sendiri berasal dari kata roman yang berasal dari bahasa perancis. tekadang pula kata tersebut ditulis dengan redaksi romant kemudian digunakan dalam bahasa Inggris dan menjadi romaunt dan ketika dinisbatkan menjadi romantic. Kata ini kemudian diserap ke dalam bahasa Jerman dan menjadi romantisch. ${ }^{25}$

Romantisme berkembang menjadi sebuah aliran sastra baru yang pertama kali dipelopori oleh seorang tokoh berkebangsaan Jerman bernama AW. Schlegel. Ia membandingkan romantisme dengan aliran klasik dan menjadikannya sebuah aliran baru dalam dunia sastra. Schlegel juga mendapati dalam perbandingan tersebut bahwa romantisme memiliki corak dan karakteristik baru dan unik yang membedakan aliran ini dengan aliran klasik, penemuan ini akhirnya sangat membantu para sastrawan dalam penggubahan karya sastra. ${ }^{26}$ Dalam dunia Arab sendiri romantisme diambil dari kata

${ }^{22}$ Muhammad Ghanimi Hilal, Al-Rumantikiyyah. Beirut: Dōrul 'Audah 1981. hal 5

${ }^{23}$ Nagham 'Ashim Utsman. Op. Cit. hal 13

24 Ibid. Hal 16-17.

25 Ibid. Hal 18

${ }^{26}$ Nagham 'Ashim Utsman. Op.Cit. Hal 19 
romanticism yang dalam bahasa Arab ditulis dengan الرومانسية (ar-Rumansiyyyah) makna kata romantisme dalam dunia Arab juga tidak jauh berbeda dengan makna yang berkembang di dunia barat, yaitu sebagaimana yang terdapat dalam Mu'jam al-Mushthalachāt al-'Arabiyyah fï lughah wal 'Adab bahwa romantisme adalah sebuah keadaan diri yang lebih mementingkan perasaan dan emosi diri dan tidak serta merta menerima kecondongan diri yang bersumber dari akal dan logika. ${ }^{27}$ Sedangkan dalam Mu'jam al-Mushthalach $\bar{\alpha} t$ al-'Adabiyyah al-Mu'ashirah romantisme dimaknai dengan sebuah aliran sastra yang muncul atas reaksi terhadap kompleksitas aliran klasik yang cenderung bersifat subjektif dan banyak aspek untuk mempertanyakan realita diri dan menggambarkan alam, serta cenderung kontradiktif dengan realita. ${ }^{28}$

Aliran Romantisme sendiri masuk ke dunia arab dan kesusastraan Arab dikarenakan kuatnya hubungan antara sastrawan Arab dengan kebudayaan barat kala itu, banyak sekali seniman dan sastrawan yang kemudian belajar ke prancis, inggris, amerika dan negara barat lainnya. Khalīl Muthran dan Khalīl Gibran termasuk salah dua dari banyaknya sastrawan Arab yang kemudian pergi ke barat untuk menimba ilmu dan kemudian memperkenalkan ilmu baru tersebut ke dalam kesusastraan Arab, sebagaimana pula yang telah dilakukan oleh kedua Khalīl tersebut, Muthran dan Gibran.

Aliran romantisme ini menjadi sebuah aliran baru yang digemari banyak sastrawan, dan juga dinikmati oleh banyak kalangan. Hal ini dikarenakan aliran ini berusaha mengungkapkan karya yang digubah dengan ungkapan terdalam dan tertulus dari ekspresi hati dan emosional si pengarang, sehingga akan memberikan kesan dan bekas yang mendalam dibandingkan dengan aliranaliran sebelumnya yang lebih mengutamakan rasionalitas dan logika dalam pengungkapan gubahan karyanya.

\footnotetext{
${ }^{27}$ Majdi Wahbah dan Kōmil, Mu'jam al-Mushthalachāt al-'Arabiyyah fï lughah wal 'Adab (Beirut: Maktabah Lubnan, 1984) hal 189

${ }^{28}$ Sa'id 'Alv̄siy, Mu'jam al-Mushthalachōt al-'Adabiyyah al-Mu'ashirah (Beirut: Dōrul Kitāb alLubnānīy, 1985) hal 107
} 


\section{Analisis Romantisme Puisi Khalīl Muthran}

Khalīl Muthran pernah menggubah sebuah puisi yang berjudul "المساء" yang bermakna senja atau sore hari. Berikut potongan puisi senja dari Khalīl Muthran yang nantinya akan dianalisis berdasarkan ciri-ciri romantisme.

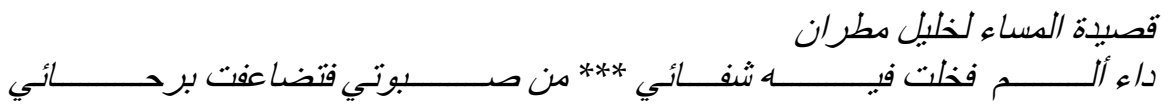

Sakit yang menyakitiku dan menghilangkan kesehatanku, merenggut sejak masa kecilku dan terus berlipat ganda seperjalanan hidupku

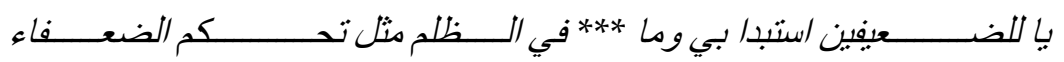

Wahai dua kelemahan yang mendzalimi diriku, sungguh tiada kedzaliman sebagaimana kesewenangan terhadap orang lemah

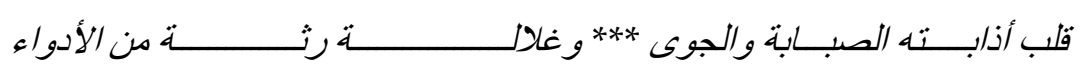

Hatiku luluh leleh karena kehampaan dan kengerian dalam meratapi obat-obat

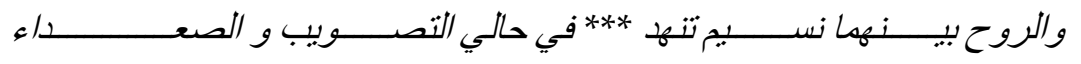

Ruh diantara keduanya bagai angin semilir yang mengalir pelan, ketika diri ini berusaha menarik nafas panjang

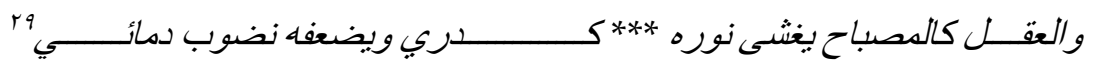

Akal bagai lentera yang diliputi oleh cahaya, namun kekeruhan yang kualami mengalirkan air mata darah

Pada cuplikan puisi ini terlihat beberapa karakteristik romantisme yang sangat kental pada puisi "المساء ciptaan Khalīl Muthran. Pada bait pertama Muthran menjelaskan mengenai penyakit yang diderita sejak kecil dan terus menggerogoti sepanjang hidupnya, disini Muthran menggambarkan rasa sakit yang begitu dalam sehingga nampak bahwasanya ungkapan tersebut berasal dari ketidaktahanan terhadap penyakit yang diderita dan perasaan memendam sakit yang begitu besar. Kemudian di bait selanjutnya, Muthran menggambarkan " dan " لألم" yang menyerang sebagai sebuah objek yang dapat diajak bicara dan dapat melakukan perbuatan tertentu sehingga Muthran menganalogikan dua hal tersebut seperti dua orang yang sedang menganiaya dan mendzolomi dirinya yang lemah.

Pada bait ketiga Muthran menggambarkan hatinya yang tengah leleh dan luluh berantakan karena kengerian dan ketidaktahanan karena terus harus mengonsumsi obat-obatan yang akan melemahkan dirinya, hal ini menunjukkan bahwa Muhtran tengah mengungkapkan perasaannya dan

${ }^{29}$ Ahmad Darwish, Khalīl Muthran al-A'mōl al-Syi'riyyah al-Kōmilah. Kuwait: Muassasah Jaizah 'Abdul 'Aziz Su'v̄d al-Bābathin lil-Ibda' al-Syi' rī, 2010. hal 103 
ketakutannya ketika harus terus mengonsumsi obat-obatan. Kemudian di bait selanjutnya Muhtran menggambarkan ruh dirinya yang diserang dua penyakit tadi bagai semepoi angin yang lewat ketika ia menarik nafas panjang, dalam bait ini Muhtran berbicara mengenai ruh yang sama sekali tidak terjamah oleh akal dan logika, ia menggambarkan ruh dan diserupakan dengan angin semilir ketika menarik nafas panjang. Pada bait terakhir Muthran mengibaratkan akal bagai lentera yang diselimuti oleh cahaya, ini juga merupakan bentuk imajinasi yang dilakukan dan diguratkan Muthran dalam puisinya, kemudian ia melanjutkan sekalipun akal itu bagai lentera yang terliputi dengan cahaya, namun kekeruhan dan penyakit yang ia derita tetap terlalu hebat hingga ia meneteskan air mata darah. Permisalan yang Muthran gambarkan tersebut juga merupakan imajinasi yang ia sampaikan, karena terlalu sakit, seakan-akan ia sampai meneteskan air mata darah.

\section{Analisis Romantisme Puisi Khalīl Gibran}

Khalīl Gibran di dalam karyanya yang berjudul "Al-Ajnichah AlMutakassirah" pernah membuat prosa yang indah mengenai ibu, gubahan kata yang beliau susun dalam mensifati seorang ibu disebut-sebut sebagai ungkapan ekspresi terindah mengenai ibu. Berikut potongan prosa Khalīl Gibran mengenai ibu ysng nantinya akan dianalisis berdasarkan ciri-ciri romantisme.

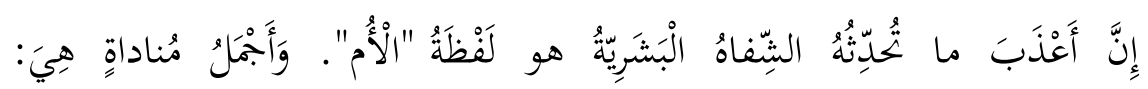

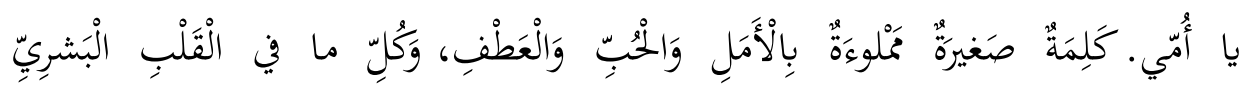

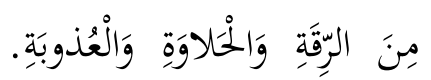

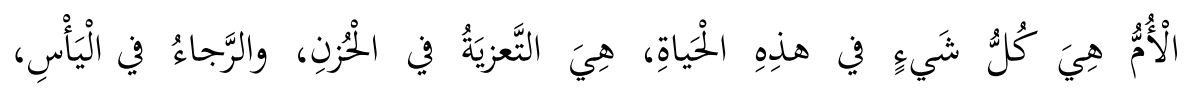

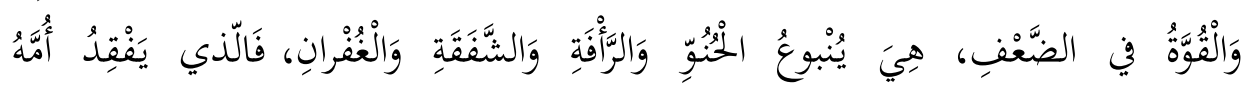

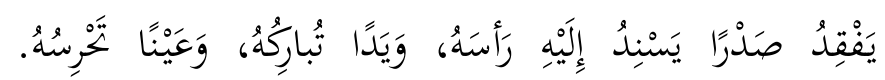

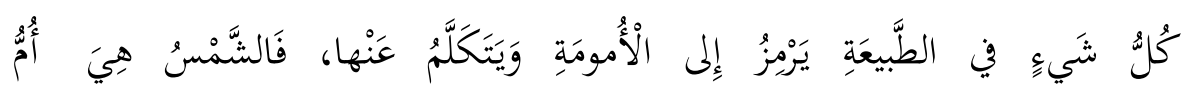

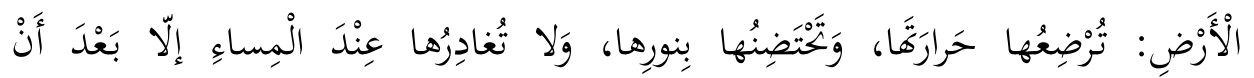

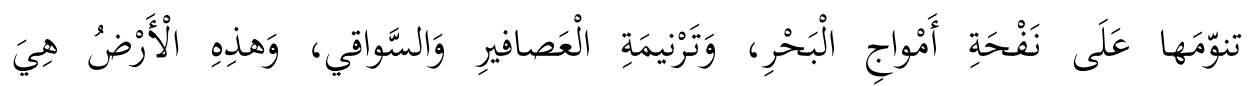

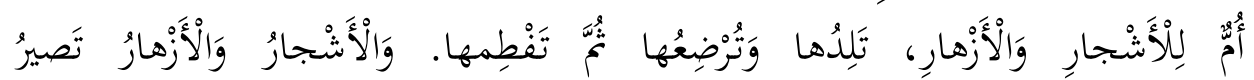




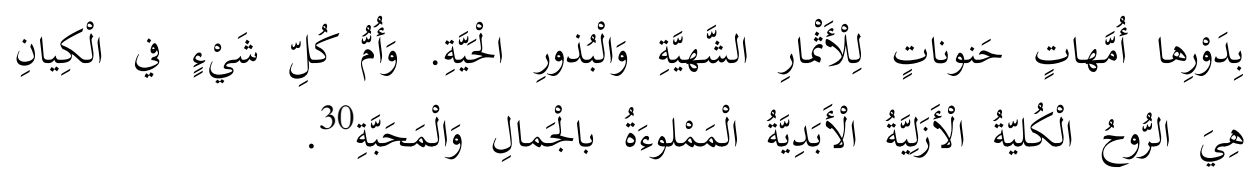

Ibu merupakan kata terindah yang terucap oleh bibir - bibir manusia. "Wahai Ibuku" merupakan panggilan terindah. Kata yang ringkas namun menebarkan semerbak cinta dan impian, manis dan syahdu yang memancar dari kedalaman jiwa. Ibu adalah sumber dari segala sesuatu. Ibu adalah penghibur kita dikala sedih, impian kata dalam rengsa, semangat kita di kala lemah. Ibu adalah mata air cinta, kemuliaan, kebahagiaan dan toleransi. Siapa pun yang kehilangan ibunya, ia seakan kehilangan hati suci yang senantiasa merestui dan memberkatinya, kehilangan tangan yang selalu menggandengnya, dan mata yang selalu menjaganya. Alam semesta selalu berbincang dalam bahasa ibu. Matahari sebagai ibu bumi yang menyusuinya melalui panasnya. Matahari tak akan pernah meninggalkan bumi sampai malam merebahkannya dalam gulungan ombak, syahdu kicauan burung dan desiran air sungai. Bumi adalah ibu dari pepohonan dan bebungaan. Bumi menumbuhkan, menjaga dan membesarkannya. Pepohonan dan bebungaan adalah ibu yang tulus memelihara bebuahan dan bebijian. Ibu adalah jiwa keabadian bagi semua wujud yang senantiasa penuh cinta dan keindahan.

Pada cuplikan prosa tentang ibu dalam buku al-Ajnichah al-Mutakassirah di atas, Khalīl Gibran sangat menampakkan aliran dan corak romantismenya. Hal ini dapat terlihat pada ungkapan kata ibu yang disifati dengan sebuah kata yang penuh dengan semerbak cinta dan impian serta manis. Kemudian corak ini juga terlihat ketika Gibran menyamakan ibu dengan sosok matahari terhadap bumi, yang senantiasa menyinari bumi dan tak tega meninggalkannya hingga ia disambut oleh gelapnya malam dan desiran sungai. Pun halnya ketika ibu diibaratkan dengan bumi yang mengayomi pepohonan dan bunga-bunga.

Segala bentuk penyerupaan dengan hal-hal yang tidak rasional dan juga penggambaran alam dalam mengekspresikan rasa dalam cuplikan prosa di atas menjadi bukti kuat dan nyata atas corak romantisme yang melekat pada Khalīl Gibran selaku tokoh sastrawan Arab yang mempopulerkan aliran romantisme dalam dunia Arab.

${ }^{30}$ Khalīl Gibran, al-Ajnichah al-Mutakasirrah. Beirut: al-Maktabah al-Tsaqafiyyah, tt. Hal 


\section{Penutup}

Berdasarkan uraian diatas, dapat disimpulkan bahwa romantisme adalah salah satu aliran baru yang muncul pada abad 18 di barat. Kemunculan aliran ini dalam kesusastraan Arab diadaptasi oleh sastrawan Arab, yaitu Khalīl Muhtran. Muthran merupakan sosok sastrawan cerdas yang menimba ilmu di barat dan mengadopsi serta mempelajari aliran romantisme untuk ia terapkan dalam syairsyair yang ia gubah. Selain Khalīl Muthran, adalagi sosok "Khalīl" yang menjadi tokoh romantisme dalam kesusastraan Arab, yakni Khalīl Gibran. Gibran adalah seorang seniman dan sastrawan ulung yang diakui dunia akan kehebatannya dalam merangkai kata dan melukis. Ia juga dikenal sebagai tokoh penting dalam romantisme sastra Arab karena karya-karyanya yang sangat kental akan unsurunsur romantisme. Gibran juga pernah belajar di barat untuk mendalami dan mempelajari aliran romantisme yang membuatnya besar hingga saat ini.

Karakteristik dan ciri romantisme sangat kuat dan nampak pada karya dari kedua Khalīl ini. Syair "al-Mas $\bar{\alpha}^{\prime \prime}$ dari Muthran, dan prosa tentang ibu dalam kitab al-Ajnichah al-Mutakassirah dari Gibran menjadi bukti akan corak romantisme yang kuat dari kedua tokoh ini. Penggambaran tentang alam, penyerupaan terhadap sesuatu yang jauh dari rasionalitas, pengekspresian yang bersifat emosional, dan pengungkapan perasaan yang mendalam menjadi poinpoin penting yang menandakan ciri romantisme pada kedua karya di atas, sekaligus membuktikan bahwa Khalīl Muthran dan Khalīl Gibran (al-Khalīlayn) adalah dua tokoh penting dalam romantisme sastra Arab. 


\section{Daftar Pustaka}

'Alv̄siy, Sa'id. (1985). Mu'jam al-Mushthalachāt al-'Adabiyyah al-Mu'ashirah. Beirut: Dōrul Kitāb al-Lubnōnīy.

Anal-Bahr.com, Bachts an Sya'iri Khalīl Muthran Sya'iri al-Qathrain, diakses dari https:/ / analbahr.com/بحث_عن_الثـاعر -خليل-مطر ان-شاعر -القطرين/ pada 8 November 2020 pukul 13.05

Darwish, Ahmad. (2020). Khalīl Muthran al-A'mōl al-Syi'riyyah al-Kōmilah. Kuwait: Muassasah Jaizah 'Abdul 'Aziz Su'v̄d al-Bōbathin lil-Ibda' al-Syi'rī.

Gibran, Jean dan Khalīl Gibran. (2015). Khalīl Gibran chayātuhu wa 'al̄̄muhu. Kairo: al-Majlis al-A'lē lil-Tsaqūfah.

Gibran, Khalīl. (tt). al-Ajnichah al-Mutakasirrah. Beirut: al-Maktabah alTsaqafiyyah.

Gibran National Committee, About Gibran Biography, diakses di http:/ / www.gibranKhalīlgibran.org/AboutGebran/Biography pada 10 november 2020 pukul 10.22

Hilal, Muhammad Ghanimi. (1981). Al-Rumantikiyyah. Beirut: Dārul 'Audah. Juha, Michel. (1981). Khalīl Muthran Bakv̄rah lì al-Tajdìdi fì al-Syi'ri al-'Arabìy al-Chadìtsìy. Beirut: Dōrul Masīrah.

Manshur Said Husain. (1977). al-Tajdìd fì syi'ri khalīl Muthran. Iskandariah: alHay'ah al-Mishriyyah al-'Ammah lil-Kitāb.

Mareefa.org, Jibrōn Khalīl Jibran, diakses dari https://www.marefa.org/جبران خليل جبران pada 8 November 2020 pukul 14.07

Moloeng, Lexy J. (2017). Metodologi Penelitian Kualitatif. Bandung: Remaja Rosdakarya.

Nojomy.com, Khalīl Muthran Qishshatu chayati syō'ir al-Qathrain, diakses di https://nojomy.com/writers/خليل_مطران_قصنة_حياة pada 8 November 2020 pukul 13.50.

Sugiyono. (2005). Metode Penelitian Kuantitatif Kualitatif Dan RED. Bandung: Alfabeta.

Sukron, Kamil. (2012). Teori Kritik Sastra Arab Klasik dan Modern. Jakarta: Raja Grafindo Persada.

Utsman, Nagham 'Ashim,. (2017). Ar-Rōmansīyah Bachts fī al-Musthalach wa Tōrīkhihi wa Madzōhibihi al-Fikriyyah. al-markaz al-islamiy lildirōsat al-istirātījiyyah.

Wahbah, Majdi dan Kōmil. (1984). Mu'jam al-Mushthalachāt al-'Arabiyyah fī lughah wal 'Adab. Beirut: Maktabah Lubnan. 